\title{
ANALISIS PERBEDAAN TINGKAT PROFITABILITAS SEBELUM DAN SESUDAH PENGUNGKAPAN CSR (CORPORATE SOCIAL RESPONSIBILITY) PADA PERUSAHAAN DALAM INDUSTRI PERTAMBANGAN DAN FARMASI YANG TERDAFTAR DI BURSA EFEK INDONESIA
}

\author{
Yustina Herry; Stefanus Ariyanto \\ Accounting Department, Faculty of Economic and Communication, BINUS University \\ Jln. KH Syahdan No 9, Kemanggisan-Palmerah, Jakarta Barat 11480 \\ stefanus.ariyanto@binus.ac.id
}

\begin{abstract}
The main purpose of the company used to gain maximum profits, now has changed with more attention to environmental and social aspects (triple bottom line) in order to create balance in the implementation. The research was conducted with the aim to analyze whether there are differences in the level of profitability as seen from the ratio of profitability, namely NPM (Net Profit Margin), ROA (Return on Assets) and ROE (Return On Equity) both before and after the disclosure of Corporate Social Responsibility. The sample used in this study is companies in the mining and pharmaceutical industries listed in the Indonesia Stock Exchange disclosing CSR in the period of 2003-2008 in the annual report or separate sustainability report. There are 10 samples taken by purposive sampling method, which meets the criteria. Data were analyzed using SPSS 16.0. Hypothesis testing is performed using paired two-sample test (paired sample t-test). The result of research indicates that there are no difference in profitability at the time before and after the disclosure of CSR.
\end{abstract}

Keywords: Corporate Social Responsibility, profitability

\begin{abstract}
ABSTRAK
Tujuan utama didirikannya perusahaan yang semula semata-mata untuk memperoleh laba setinggitingginya, saat ini telah berubah dengan lebih memperhatikan aspek lingkungan dan sosial (triple bottom line) agar tercipta keseimbangan dalam pelaksanaannya. Penelitian ini dilakukan dengan tujuan untuk menganalisis apakah terdapat perbedaan tingkat profitabilitas yang dilihat dari rasio profitabilitas, yaitu NPM (Net Profit Margin), ROA (Return On Asset), dan ROE (Return On Equity) pada saat sebelum dan sesudah pengungkapan Corporate Social Responsibility. Sampel yang digunakan pada penelitian ini adalah perusahaan dalam industri pertambangan dan farmasi yang terdaftar di Bursa Efek Indonesia yang melakukan pengungkapan CSR pada periode 2003-2008 dan diungkapkan di dalam laporan tahunan. Terdapat 10 sampel yang diambil dengan metode purposive sampling, yang memenuhi kriteria. Data dianalisis dengan SPSS 16.0. Pengujian hipotesis dilakukan dengan menggunakan uji dua sampel berpasangan (paired sample t-test). Hasil penelitian yang dilakukan secara parsial menunjukkan bahwa tidak terjadi perbedaan profitabilitas pada saat sebelum dan sesudah pengungkapan CSR.
\end{abstract}

Kata kunci: profitabilitas, tanggung jawab sosial perusahaan 


\section{PENDAHULUAN}

Pemikiran yang melandasi CSR yang sering dianggap inti dari etika bisnis adalah bahwa perusahaan public tidak hanya mempunyai kewajiban-kewajiban ekonomi dan legal (artinya kepada pemegang saham atau stakeholder) tetapi juga kewajiban-kewajiban terhadap pihak-pihak lain yang berkepentingan (stakeholder) yang jangkauannya melebihi kewajiban-kewajiban di atas. Tanggung jawab sosial dari perusahaan terjadi antara sebuah perusahaan dengan semua stakeholder, termasuk di dalamnya adalah pelanggan atau customer, pegawai, komunitas, pemilik atau investor, pemerintah, supplier bahkan juga competitor (Nurlela dan Islahudin, 2008). Pada dasarnya pengungkapan tanggung jawab sosial perusahaan bertujuan untuk memperlihatkan kepada masyarakat tentang aktivitas sosial yang dilakukan oleh perusahaan dan pengaruhnya kepada masyarakat. Indonesia memiliki Undang-Undang Republik Indonesia nomor 40 tahun 2007 yang membahas tentang Perseroan Terbatas (yang merupakan hasil revisi dari Undang-Undang Nomor 1 Tahun 1995). Setelah ditetapkannya Undang-Undang Nomor 40 Tahun 2007, perusahaan public yang terdaftar di Bursa Efek Indonesia mengungkapkan aktivitas sosial dan lingkungannya dalam laporan tahunan (Annual Report) ataupun di buat terpisah yang disebut Sustainability Report. Dengan adanya laporan tahunan, para investor, dan juga stakeholder dapat mengetahui secara transparan tanggung jawab sosial apa saja yang telah dilakukan oleh perusahaan.

Pengukuran pengungkapan sosial dilakukan dengan menggunakan instrumen penelitian berupa daftar item pengungkapan sosial berdasarkan penelitian yang dilakukan oleh Hackston dan Milne (1996) dan Istiqomah, (2011). Perusahaan akan memperoleh legitimasi sosial dan memaksimalkan kekuatan keuangannya dalam jangka panjang melalui penerapan CSR (kiroyan, 2006: 45 dalam Istiqomah 2011). Penelitian ini mengacu pada penelitian Lailatul Istiqomah (2011). Penelitian tersebut melakukan analisis profitabilitas perusahaan sebelum dan setelah melaksanakan program CSR pada industri telekomunikasi. Hasil dari kesimpulan yang didapat adalah terdapat perbedaan ROA (Return On Asset) sebelum dan setelah melaksanakan program corporate social responsibility pada industri telekomunikasi. Sedangkan ROE (Return On Equity), dan NPM (Net Profit Margin) tidak mengalami perbedaan sebelum dan setelah melaksanakan program corporate social responsibility pada industri telekomunikasi. Dengan memperhatikan latar belakang dan perumusan masalah di atas, maka dapat dirumuskan tujuan dilaksanakannya penelitian ini adalah untuk turut serta memberikan kontribusi penulis terhadap wacana, pemikiran, kajian mengenai karakteristik perusahaan terhadap pengungkapan CSR. Selain itu juga bertujuan untuk menguji apakah terdapat perbedaan profitabilitas sebelum dan sesudah melakukan pengungkapan CSR pada perusahaan dalam industri pertambangan dan farmasi.

\section{METODE}

Pendekatan yang digunakan dalam penelitian ini adalah menggunakan pendekatan kuantitatof dengan pengujian hipotesis. Data penelitian diolah dengan menggunakan Statistical Product and Solution Services (SPSS) 16.0. Pengujian hipotesis dilakukan dengan melakukan uji t berpasangan (paired sample t-test). Pengujian ini akan membandingkan kinerja perusahaan tahun sebelum dan sesudah pengungkapan CSR. Teknik analisis data yang dilakukan adalah dengan melakukan uji statistik deskriptif yang bertujuan untuk mengetahui tingkat penerapan CSR dan profitabilitas pada perusahaan dalam industri pertambangan dan farmasi yang terdaftar di Bursa Efek Indonesia. Pengukuran yang digunakan dalam penelitian ini adalah nilai rata-rata (mean), maksimum, minimum, standar deviasi, dan varian indikator kinerja keuangan perusahaan dari rasio profitabilitas sebelum dan sesudah pengungkapan CSR dari perusahaan dalam industri pertambangan dan farmasi yang terdaftar di BEI serta menentukan perbedaan mean (naik/turun) indikator keuangan perusahaan antara sebelum dan sesudah pengungkapan CSR. Sebelumnya, data yang ada akan dilakukan uji normalitas untuk 
mendeteksi normalitas data dengan uji metode kolmogorov-smirnov test. Setelah dilakukan uji normalitas, maka selanjutnya dilakukan analisis data dengan uji $\mathrm{t}$ berpasangan (paired sample t-test). Jenis data yang digunakan dalam penelitian adalah data sekunder, yaitu laporan keuangan, laporan tahunan, ataupun laporan berkelanjutan perusahaan (sustainability report) dari perusahaan-perusahaan yang terdaftar di Bursa Efek Indonesia yang diambil langsung dari portal Bursa Efek Indonesia (www.idx.co.id).

\section{Landasan Teori}

Corporate Social Responsibility dalam bahasa Indonesia dikenal dengan tanggung jawab sosial perusahaan, sedangkan di Amerika, konsep ini seringkali disamakan dengan corporate citizenship. Pada intinya, keduanya dimaksudkan sebagai upaya perusahaan untuk meningkatkan kepedulian terhadap masalah sosial dan lingkungan dalam kegiatan usaha dan juga pada cara perusahaan berinteraksi dengan stakeholder yang dilakukan secara sukarela. Selain itu, tanggung jawab sosial perusahaan diartikan pula sebagai komitmen bisnis untuk berkontribusi dalam pembangunan ekonomi berkelanjutan, bekerja dengan para karyawan perusahaan, keluarga karyawan dan masyarakat setempat (local) dalam rangka meningkatkan kualitas kehidupan.

Dalam berbagai wacana, Corporate Social Responsibility dapat diartikan secara luas dan universal seperti berikut: komitmen berkesinambungan dari kalangan bisnis untuk berperilaku etis dan memberi kontribusi bagi pembangunan ekonomi, sambil meningkatkan kualitas kehidupan karyawan dan keluarganya, serta komunitas lokal dan masyarakat luas pada umumnya (World Business Council for Sustainable Development); komitmen dunia bisnis untuk memberi kontribusi terhadap pembangunan ekonomi berkelanjutan melalui kerjasama dengan karyawan, keluarga mereka, komunitas lokal dan masyarakat luas untuk meningkatkan kehidupan mereka melalui cara-cara yang baik bagi bisnis maupun pembangunan (International Finance Corporation); Jaminan bahwa organisasi-organisasi pengelola bisnis mampu memberi dampak positif bagi masyarakat dan lingkungan, sambil memaksimalkan nilai bagi para pemegang saham (shareholders) mereka (Institute of Chartered Accountants, England, and Wales); Sebuah konsep dengan mana perusahaan mengintegrasikan perhatian terhadap sosial dan lingkungan dalam operasi bisnis mereka dan dalam interaksinya dengan para pemangku kepentingan (stakeholders) berdasarkan prinsip kesukarelaan (European Commission); Komitmen perusahaan untuk beroperasi secara berkelanjutan berdasarkan prinsip ekonomi, sosial dan lingkungan, seraya menyeimbangkan beragam kepentingan para stakeholders (CSR Asia).

Berdasarkan standar dari Bank Dunia, CSR meliputi beberapa komponen utama, yakni: (1) perlindungan lingkungan, (2) jaminan kerja, (3) hak asasi manusia, (4) interaksi dan keterlibatan perusahaan dengan masyarakat, (5) standar usaha, (6) pasar, (7) pengembangan ekonomi dan badan usaha, (8) perlindungan kesehatan, (9) kepemimpinan dan pendidikan, (10) bantuan bencana kemanusiaan.

Bagi perusahaan yang berupaya untuk membangun citra positif perusahaannya, maka kesepuluh komponen tersebut harus diupayakan pemenuhannya. Prince of Wales International Business Forum mengungkapkan bahwa ada 5 pilar aktivitas dari CSR (Ancok, 2005: 19-20), yaitu: (1) Building Human Capital; secara internal, perusahaan dituntut untuk menciptakan SDM yang handal, secara eksternal perusahaan dituntut untuk melakukan pemberdayaan masyarakat, biasanya melalui community development. (2) Strengthening economies; perusahaan dituntut untuk tidak menjadi kaya sendiri sementara komunitas di lingkungannya miskin, mereka harus memberdayakan ekonomi sekitar. (3) Assesing Social Chesion; perusahaan dituntut untuk menjaga keharmonisan dengan masyarakat sekitar agar tidak menimbulkan konflik. (4) Encouraging Good Governance; dalam menjalankan bisnisnya, perusahaan harus menjalankan tata kelola bisnis dengan baik. (5) Protecting the Environment; Perusahaan harus berupaya menjaga kelestarian lingkungan. 
Di bawah ini kegiatan-kegiatan CSR sesuai dengan Triple bottom line, antara lain:

Tabel 1 Kegiatan CSR Triple Bottom Line

\begin{tabular}{lll}
\hline $\mathbf{N}$ & Aspek & Muatan \\
\hline \multirow{2}{*}{$\mathbf{1}$ Sosial } & & $\begin{array}{l}\text { Pendidikan, pelatihan, kesehatan, perumahan penguatan } \\
\text { kelembagaan (secara internal, termasuk kesejahteraan } \\
\text { karyawan) kesejahteraan sosial, olahraga, pemuda, wanita, } \\
\text { agama, kebudayaan dan sebagainya. }\end{array}$ \\
& & $\begin{array}{l}\text { Kewirausahaan, kelompok usaha bersama / unit mikro kecil } \\
\text { dan menengah (KUB/UMKM), agrobisnis, pembukaan } \\
\text { lapangan kerja, infrastruktur ekonomi dan usaha produktif } \\
\text { lain. }\end{array}$ \\
& & $\begin{array}{l}\text { Penghijauan, reklamasi lahan, pengelolaan, Pelestarian alam, } \\
\text { ekowisata penyehatan lingkungan, pengendalian polusi, } \\
\text { serta penggunaan produksi dan energi secara efisien. }\end{array}$ \\
& & Lingkunan
\end{tabular}

Profitabilitas adalah kemampuan perseroan untuk menghasilkan suatu keuntungan dan Menyokong Pertumbuhan baik untuk jangka pendek maupun jangka panjang (Sumber: Wikipedia). Profitabilitas merupakan faktor yang seharusnya mendapat perhatian penting karena untuk dapat melangsungkan hidupnya, suatu perusahaan harus berada dalam keadaan yang menguntungkan (profitable). Tanpa adanya keuntungan (profit), oleh karena itu akan sulit bagi perusahaan untuk menarik modal dari luar. Dalam melakukan analisis perusahaan, di samping melihat laporan keuangan perusahaan bisa dilakukan dengan menggunakan analisis rasio keuangan. Profitabilitas suatu perusahaan dapat diukur dengan menghubungkan antara keuntungan atau laba yang diperoleh dari kegiatan pokok perusahaan dengan kekayaan atau asset yang dimiliki untuk menghasilkan keuntungan perusahaan (operating asset). Penggunaan rasio profitabilitas dapat dilakukan dengan menggunakan perbandingan antara berbagai komponen yang ada di dalam laporan keuangan, terutama laporan keuangan neraca dan laporan laba rugi. Pengukuran dapat dilakukan untuk beberapa periode operasi. Tujuannya adalah agar terlihat perkembangan perusahaan dalam rentang waktu tertentu, baik penurunan atau kenaikan, sekaligus mencari penyebab perubahan tersebut. Oleh karena itu, rasio profitabilitas ini sering disebut sebagai salah satu alat ukur kinerja manajemen. Dalam penelitian ini rasio profitabilitas yang dipakai adalah Net Profit Margin (NPM), Return On Asset (ROA), dan Return On Equity (ROE).

\section{HASIL DAN PEMBAHASAN}

Gambaran variabel yang digunakan dalam penelitian ini, meliputi NPM, ROA, dan ROE. Berikut akan ditampilkan hasil dari analisis statistik deskriptif variabel yang ditinjau dari nilai rata-rata (mean), standar deviasi, nilai maksimum, dan nilai minimum untuk periode sebelum melakukan CSR. 
Tabel 2 Deskriptif Variabel Sebelum Melakukan CSR

\begin{tabular}{lccccc}
\hline Periode & Variael & Mean & Standar Deviasi & Max & Min \\
\hline $\begin{array}{l}\text { 2 Tahun sebelum } \\
\text { CSR }\end{array}$ & NPM (\%) & 0,1184 & 0,0787 & 0,2590 & 0,0054 \\
& ROA (\%) & 0,1202 & 0,0782 & 0,2855 & 0,0037 \\
& ROE (\%) & 0,3371 & 0,2007 & 0,7264 & 0,1180 \\
1 Tahun sebelum & NPM (\%) & 0,1201 & 0,0756 & 0,2758 & 0,0074 \\
CSR & ROA (\%) & 0,1206 & 0,0799 & 0,2646 & 0,0053 \\
& ROE (\%) & 0,2872 & 0,1679 & 0,6176 & 0,0700
\end{tabular}

(Sumber : Perhitungan Output Software Statistic)

Hasil deskriptif variabel sebelum melakukan CSR yang ditampilkan pada tabel 2 dapat dijelaskan sebagai berikut.

\section{Periode Dua Tahun sebelum CSR}

Nilai rata-rata kemampuan perusahaan untuk menghasilkan keuntungan dari penjualan yang dicapai (NPM) untuk periode dua tahun sebelum dilakukannya CSR adalah sebesar 0,1184, dengan standar deviasi sebesar 0,0787. Nilai standar deviasi yang lebih kecil dari nilai rata-rata menunjukkan tidak adanya variasi yang besar antara nilai maksimum dan minimum terhadap nilai rata-rata. Dengan nilai standar deviasi sebesar 0,0787 menunjukkan bahwa nilai rata-rata dari NPM adalah sebesar 0,0397 sampai 0,1971. Sedangkan untuk nilai maksimum dan minimum yang dihasilkan melalui statistik deskriptif yaitu 0,2590 dan 0,0054. Nilai rata-rata kemampuan perusahaan untuk menghasilkan laba dari aset yang dimiliki $(R O A)$ untuk periode dua tahun sebelum dilakukannya $C S R$ adalah sebesar 0,1202, dengan standar deviasi sebesar 0,0782. Nilai standar deviasi yang lebih kecil dari nilai rata-rata menunjukkan tidak adanya variasi yang besar antara nilai maksimum dan minimum terhadap nilai rata-rata. Dengan nilai standar deviasi sebesar 0,0782 menunjukkan bahwa nilai ratarata dari $R O A$ adalah sebesar 0,0420 sampai 0,1984 . Sedangkan untuk nilai maksimum dan minimum yang dihasilkan melalui statistik deskriptif yaitu 0,2855 dan 0,0037 . Nilai rata-rata efektivitas perusahaan pada tingkat pengembalian atas ekuitas saham biasa (ROE) untuk periode dua tahun sebelum dilakukannya CSR adalah sebesar 0,3371, dengan standar deviasi 0,2007. Nilai standar deviasi yang kecil menunjukkan tidak adanya variasi yang sangat besar antara nilai maksimum dan minimum terhadap nilai rata-rata. Nilai standar deviasi sebesar 0,2007 , menunjukkan bahwa nilai ratarata dari $R O E$ adalah sebesar 0,1364 sampai 0,5378 . Sedangkan masing-masing nilai maksimum dan minimumnya adalah 0,7264 dan 0,1180 .

\section{Periode Satu Tahun Sebelum CSR}

Nilai rata-rata kemampuan perusahaan untuk menghasilkan keuntungan dari penjualan yang dicapai $(N P M)$ untuk periode satu tahun sebelum dilakukannya CSR adalah sebesar 0,1201, nilai standar deviasi sebesar 0,0756 . Adanya pertumbuhan terhadap nilai rata-rata $N P M$, yaitu sebesar $0,18 \%$ dari dua tahun sebelum ke satu tahun sebelum dilakukannya CSR. Hal ini menunjukkan perusahaan mengalami peningkatan terhadap penjualannya. Nilai standar deviasi yang kecil menunjukkan tidak adanya variasi yang sangat besar antara nilai maksimum dan minimum. Nilai standar deviasi sebesar 0,0756, menunjukkan bahwa nilai rata-rata dari NPM adalah sebesar 0,0445 sampai 0,1957. Sedangkan masing-masing nilai maksimum dan minimumnya adalah 0,2758 dan 0,0074. Nilai rata-rata kemampuan perusahaan untuk menghasilkan laba dari aset yang dimiliki $(R O A)$ untuk periode satu tahun sebelum dilakukannya CSR adalah sebesar 0,1206, nilai standar deviasi sebesar 0,0799 . Adanya peningkatan rata-rata $R O A$ sebesar $0,04 \%$ dari dua tahun sebelum ke satu 
tahun sebelum dilakukannya CSR. Hal ini menunjukkan perusahaan mengalami peningkatan dalam memanfaatkan aset yang dimilikinya untuk menghasilkan laba. Nilai standar deviasi yang lebih kecil dari nilai rata-rata menunjukkan tidak adanya variasi yang besar antara nilai maksimum dan minimum terhadap nilai rata-rata. Dengan nilai standar deviasi sebesar 0,0799 menunjukkan bahwa nilai ratarata dari $R O A$ adalah sebesar 0,0408 sampai 0,2005 . Sedangkan untuk nilai maksimum dan minimum yang dihasilkan melalui statistik deskriptif yaitu 0,2646 dan 0,0053 . Nilai rata-rata efektivitas perusahaan pada tingkat pengembalian atas ekuitas saham biasa $(R O E)$ untuk periode satu tahun sebelum dilakukannya CSR adalah sebesar 0,2872, dengan standar deviasi 0,1679. Terjadi penurunan nilai rata-rata sebesar $4,98 \%$ terhadap $R O E$ dari dua tahun sebelum ke satu tahun sebelum dilakukannya CSR. Hal ini disebabkan menurunnya tingkat efektivitas perusahaan dalam hal pengembalian ekuitas saham kepada investor. Nilai standar deviasi yang kecil menunjukkan tidak adanya variasi yang sangat besar antara nilai maksimum dan minimum terhadap nilai rata-rata. Nilai standar deviasi sebesar 0,1679, menunjukkan bahwa nilai rata-rata dari ROE adalah sebesar 0,1193 sampai 0,4551. Sedangkan masing-masing nilai maksimum dan minimumnya adalah 0,6176 dan 0,0700 .

Berikut akan ditampilkan hasil dari analisis statistik deskriptif variabel yang ditinjau dari nilai rata-rata (mean), standar deviasi, nilai maksimum, dan nilai minimum untuk periode sesudah melakukan CSR.

Tabel 3 Deskriptif Variabel Sesudah Melakukan CSR

\begin{tabular}{lccccc}
\hline Periode & Variabel & Mean & $\begin{array}{c}\text { Standar } \\
\text { Deviasi }\end{array}$ & Max & Min \\
\hline 1 Tahun sesudah CSR & NPM (\%) & 0,1518 & 0,0540 & 0,2367 & 0,0891 \\
& ROA (\%) & 0,1731 & 0,1128 & 0,3600 & 0,0500 \\
& ROE (\%) & 0,2992 & 0,1327 & 0,5300 & 0,1316 \\
2 Tahun sesudah CSR & NPM (\%) & 0,1238 & 0,0726 & 0,3048 & 0,0520 \\
& ROA (\%) & 0,1444 & 0,1075 & 0,3380 & 0,0259 \\
3 Tahun sesudah CSR & ROE (\%) & 0,2331 & 0,1215 & 0,4780 & 0,0746 \\
& NPM (\%) & 0,1412 & 0,0735 & 0,2540 & 0,0400 \\
& ROA (\%) & 0,1506 & 0,1181 & 0,3460 & 0,0190 \\
& ROE (\%) & 0,2438 & 0,1406 & 0,5053 & 0,0650 \\
\hline
\end{tabular}

(Sumber: Hasil Output Software Statistic)

Hasil deskriptif variabel sesudah melakukan CSR yang ditampilkan pada tabel 3 dapat dijelaskan sebagai berikut.

\section{Periode satu tahun sesudah $C S R$}

Nilai rata-rata kemampuan perusahaan untuk menghasilkan keuntungan dari penjualan yang dicapai (NPM) untuk periode satu tahun sesudah dilakukannya CSR adalah sebesar 0,1518, dengan standar deviasi sebesar 0,0540. Nilai standar deviasi yang kecil menunjukkan tidak adanya variasi yang sangat besar antara nilai maksimum dan minimum. Nilai standar deviasi sebesar 0,0540, menunjukkan bahwa nilai rata-rata dari $N P M$ adalah sebesar 0,0978 sampai 0,2058. Sedangkan masing-masing nilai maksimum dan minimumnya adalah 0,2367 dan 0,0891. Nilai rata-rata kemampuan perusahaan untuk menghasilkan laba dari aset yang dimiliki $(R O A)$ untuk periode satu tahun sesudah dilakukannya CSR adalah sebesar 0,1731 , nilai standar deviasi sebesar 0,1128 . Nilai standar deviasi yang lebih kecil dari nilai rata-rata menunjukkan tidak adanya variasi yang besar antara 
nilai maksimum dan minimum terhadap nilai rata-rata. Nilai standar deviasinya sebesar 0,1128 menunjukkan bahwa nilai rata-rata dari $R O A$ adalah sebesar 0,0603 sampai 0,2859 . Sedangkan untuk nilai maksimum dan minimum yang dihasilkan melalui statistik deskriptif yaitu 0,3600 dan 0,0500 . Nilai rata-rata efektivitas perusahaan pada tingkat pengembalian atas ekuitas saham biasa (ROE) untuk periode satu tahun sesudah dilakukannya CSR adalah sebesar 0,2992, nilai standar deviasi 0,1327 . Nilai standar deviasi yang kecil menunjukkan tidak adanya variasi yang sangat besar antara nilai maksimum dan minimum terhadap nilai rata-rata. Nilai standar deviasi sebesar 0,1327 , menunjukkan bahwa nilai rata-rata dari $R O E$ adalah sebesar 0,1664 sampai 0,4319 . Sedangkan masing-masing nilai maksimum dan minimumnya adalah 0,5300 dan 0,1316 .

\section{Periode Dua Tahun Sesudah CSR}

Nilai rata-rata kemampuan perusahaan untuk menghasilkan keuntungan dari penjualan yang dicapai (NPM) untuk periode dua tahun sesudah dilakukannya CSR adalah sebesar 0,1238, nilai standar deviasi sebesar 0,0726 . Adanya penurunan terhadap nilai rata-rata $N P M$, yaitu sebesar $2,80 \%$ dari satu tahun sesudah ke dua tahun sesudah dilakukannya CSR. Hal ini menunjukkan perusahaan mengalami penurunan terhadap penjualannya. Nilai standar deviasi yang kecil menunjukkan tidak adanya variasi yang sangat besar antara nilai maksimum dan minimum. Nilai standar deviasi sebesar 0,0726, menunjukkan bahwa nilai rata-rata dari $N P M$ adalah sebesar 0,0512 sampai 0,1964 . Sedangkan masing-masing nilai maksimum dan minimumnya adalah 0,3048 dan 0,0520 . Nilai ratarata kemampuan perusahaan untuk menghasilkan laba dari aset yang dimiliki $(R O A)$ untuk periode dua tahun sesudah dilakukannya CSR adalah sebesar 0,1444 , nilai standar deviasi sebesar 0,1075 . Terjadi penurunan terhadap nilai rata-rata $R O A$ sebesar $2,88 \%$ dari satu tahun sesudah ke dua tahun sesudah dilakukannya CSR. Hal ini menunjukkan perusahaan mengalami penurunan dalam memanfaatkan aset yang dimilikinya untuk menghasilkan laba. Nilai standar deviasi yang lebih kecil dari nilai rata-rata menunjukkan tidak adanya variasi yang besar antara nilai maksimum dan minimum terhadap nilai rata-rata. Nilai standar deviasi yang sebesar 0,1075 menunjukkan bahwa nilai rata-rata dari $R O A$ adalah sebesar 0,0369 sampai 0,2518. Sedangkan untuk nilai maksimum dan minimum yang dihasilkan melalui statistik deskriptif yaitu 0,3380 dan 0,0259 . Nilai rata-rata efektivitas perusahaan pada tingkat pengembalian atas ekuitas saham biasa (ROE) untuk periode dua tahun sesudah dilakukannya CSR adalah sebesar 0,2331, nilai standar deviasi 0,1215 . Terjadi penurunan terhadap nilai rata-rata $R O E$ sebesar $6,61 \%$ dari satu tahun sesudah ke dua tahun sesudah dilakukannya $C S R$. Hal ini disebabkan menurunnya tingkat efektivitas perusahaan dalam hal pengembalian ekuitas saham kepada investor. Nilai standar deviasi yang kecil menunjukkan tidak adanya variasi yang sangat besar antara nilai maksimum dan minimum terhadap nilai rata-rata. Nilai standar deviasi sebesar 0,1215 , menunjukkan bahwa nilai rata-rata dari $R O E$ adalah sebesar 0,1116 sampai 0,3545 . Sedangkan masing-masing nilai maksimum dan minimumnya adalah 0,4780 dan 0,0746 .

\section{Periode Tiga Tahun Sesudah CSR}

Nilai rata-rata kemampuan perusahaan untuk menghasilkan keuntungan dari penjualan yang dicapai $(N P M)$ untuk periode tiga tahun sesudah dilakukannya CSR adalah sebesar 0,1412 , nilai standar deviasi sebesar 0,0735. Adanya peningkatan terhadap nilai rata-rata NPM, yaitu sebesar 1,74\% dari dua tahun sesudah ke tiga tahun sesudah dilakukannya CSR. Hal ini menunjukkan perusahaan mengalami peningkatan kembali terhadap penjualannya. Nilai standar deviasi yang kecil menunjukkan tidak adanya variasi yang sangat besar antara nilai maksimum dan minimum. Nilai standar deviasi sebesar 0,0735, menunjukkan bahwa nilai rata-rata dari NPM adalah sebesar 0,0677 sampai 0,2147. Sedangkan masing-masing nilai maksimum dan minimumnya adalah 0,2540 dan 0,0400 . Nilai ratarata kemampuan perusahaan untuk menghasilkan laba dari aset yang dimiliki $(R O A)$ untuk periode tiga tahun sesudah dilakukannya CSR adalah sebesar 0,1506 , nilai standar deviasi sebesar 0,1181 . Terjadi peningkatan terhadap nilai rata-rata $R O A$ sebesar $0,62 \%$ dari dua tahun sesudah ke tiga tahun sesudah dilakukannya CSR. Hal ini menunjukkan perusahaan mengalami peningkatan kembali dalam memanfaatkan aset yang dimilikinya untuk menghasilkan laba. Nilai standar deviasi yang lebih kecil 
dari nilai rata-rata menunjukkan tidak adanya variasi yang besar antara nilai maksimum dan minimum terhadap nilai rata-rata. Nilai standar deviasi sebesar 0,1181 menunjukkan bahwa nilai rata-rata dari $R O A$ adalah sebesar 0,0325 sampai 0,2686. Dan untuk nilai maksimum dan minimum yang dihasilkan melalui statistik deskriptif yaitu 0,3460 dan 0,0190 . Nilai rata-rata efektivitas perusahaan pada tingkat pengembalian atas ekuitas saham biasa $(R O E)$ untuk periode tiga tahun sesudah dilakukannya $C S R$ adalah sebesar 0,2438 , nilai standar deviasi 0,1406 . Terjadi peningkatan terhadap nilai rata-rata $R O E$ sebesar $1,07 \%$ dari dua tahun sesudah ke tiga tahun sesudah dilakukannya CSR. Hal ini disebabkan meningkatnya tingkat efektivitas perusahaan dalam hal pengembalian ekuitas saham kepada investor. Nilai standar deviasi yang kecil menunjukkan tidak adanya variasi yang sangat besar antara nilai maksimum dan minimum terhadap nilai rata-rata. Nilai standar deviasi sebesar 0,1406 , menunjukkan bahwa nilai rata-rata dari $R O E$ adalah sebesar 0,1031 sampai $0,3844 \%$. Sedangkan masing-masing nilai maksimum dan minimumnya adalah 0,5053 dan 0,0650 .

Analisis data pada penelitian ini dimulai dengan melakukan uji normalitas terhadap variabelvariabel yang digunakan dalam penelitian ini, yaitu $N P M, R O A$, dan ROE. Uji Normalitas digunakan untuk menentukan analisis berikutnya yang akan digunakan apakah uji parametrik atau non parametrik. Setelah uji normalitas dilakukan, akan dilakukan analisis data melalui rasio-rasio keuangan yang menyangkut kinerja keuangan perusahaan.

Pada uji normalitas data akan dilakukan dengan menggunakan metode Kolmogorov-Smirnov Test. Pemilihan metode ini didasarkan bahwa kolmogorov-smirnov test merupakan metode pengujian normalitas yang umum dan banyak digunakan untuk menguji normalitas data. Tujuan pengujian ini adalah untuk mengetahui apakah sampel yang digunakan dalam penelitian ini adalah berdistribusi normal atau tidak. Sampel berdistribusi normal apabila Asymptotic sig $>$ tingkat keyakinan yang digunakan dalan pengujian, dalam hal ini adalah $95 \%$ atau $\alpha 5 \%$. Sebaliknya dikatakan tidak normal apabila Asymptotic sig < tingkat keyakinan. Jika hasil menunjukkan sampel berdistribusi normal, uji beda yang akan digunakan dalam penelitian ini uji parametrik (paired sample t-test). Dan jika sampel berdistribusi tidak normal, maka uji beda yang akan digunakan dalam penelitian ini adalah uji non parametrik.

Hasil dari uji normalitas terhadap data rasio-rasio keuangan dengan menggunakan metode Kolmogorov-Smirnov Test untuk periode sebelum dan sesudah pengungkapan CSR dapat dilihat pada tabel 4 berikut.

Tabel 4 Hasil Uji Normalitas Data Rasio-Rasio Keuangan

\begin{tabular}{|c|c|c|c|c|}
\hline Periode & Variabel & AsymptoticSig & $\begin{array}{c}\text { Nilai Prob. } \\
\text { Terhadap } \alpha=0,05\end{array}$ & Kesimpulan \\
\hline \multirow[t]{3}{*}{2 Tahun sebelum $C S R$} & $N P M(\%)$ & 0,200 & 0,05 & Normal \\
\hline & $R O A(\%)$ & 0,200 & 0,05 & Normal \\
\hline & ROE (\%) & 0,200 & 0,05 & Normal \\
\hline \multirow[t]{3}{*}{1 Tahun sebelum $C S R$} & $N P M(\%)$ & 0,200 & 0,05 & Normal \\
\hline & $R O A(\%)$ & 0,200 & 0,05 & Normal \\
\hline & $R O E(\%)$ & 0,200 & 0,05 & Normal \\
\hline \multirow[t]{3}{*}{1 Tahun sesudah $C S R$} & $N P M(\%)$ & 0,200 & 0,05 & Normal \\
\hline & $R O A(\%)$ & 0,136 & 0,05 & Normal \\
\hline & ROE (\%) & 0,200 & 0,05 & Normal \\
\hline \multirow[t]{3}{*}{2 Tahun sesudah $C S R$} & $N P M(\%)$ & 0,126 & 0,05 & Normal \\
\hline & $R O A(\%)$ & 0,200 & 0,05 & Normal \\
\hline & $R O E(\%)$ & 0,200 & 0,05 & Normal \\
\hline \multirow[t]{3}{*}{3 Tahun sesudah $C S R$} & $N P M(\%)$ & 0,200 & 0,05 & Normal \\
\hline & $R O A(\%)$ & 0,200 & 0,05 & Normal \\
\hline & ROE (\%) & 0,200 & 0,05 & Normal \\
\hline
\end{tabular}

(Sumber : Perhitungan Output Software Statistic) 
Berdasarkan hasil uji normalitas data diatas, terlihat bahwa keseluruhan data yang telah di uji berdistribusikan normal, oleh karena Asymptotic sig > tingkat keyakinan yang digunakan dalam pengujian, yaitu $\alpha=5 \%$. Jika hasil menunjukkan data berdistribusi normal, maka uji beda yang akan digunakan dalam penelitian ini adalah uji parametrik (paired sample t-test). Pendapat ini juga didukung dari hasil penelitian Agustin (2011) yang menggunakan uji parametrik dalam penelitiannya mengenai perbedaan profitabilitas. Maka dari itu, Paired Sample T-Test akan digunakan untuk menguji data rasio keuangan untuk menguji hipotesis secara parsial dalam penelitian ini.

Berdasarkan dari hasil analisis dan uji hipotesis yang telah dilakukan, maka dapat diringkas sebagai berikut. Hipotesa pertama yang menyatakan terdapat perbedaaan NPM antara sebelum dan sesudah pengungkapan program CSR. Hal ini telah dibuktikan dengan hasil uji Paired Sample T-Test dimana nilai signifikansi yang didapat adalah sebagai berikut.

Tabel 5 Hasil Paired Sample T-Test terhadap NPM

\begin{tabular}{cccc}
\hline Periode & $\begin{array}{c}\text { Sig } \\
\text { (2-tailed) }\end{array}$ & $\begin{array}{c}\text { Nilai Prob. } \\
\text { terhadap } \boldsymbol{\alpha}=\mathbf{0 , 0 5}\end{array}$ & Kesimpulan \\
\hline 1 tahun sebelum dan 1 tahun sesudah & 0,327 & 0,05 & $\mathrm{H}_{01}$ diterima \\
1 tahun sebelum dan 2 tahun sesudah & 0,914 & 0,05 & $\mathrm{H}_{01}$ diterima \\
1 tahun sebelum dan 3 tahun sesudah & 0,419 & 0,05 & $\mathrm{H}_{01}$ diterima \\
2 tahun sebelum dan 1 tahun sesudah & 0,306 & 0,05 & $\mathrm{H}_{01}$ diterima \\
2 tahun sebelum dan 2 tahun sesudah & 0,866 & 0,05 & $\mathrm{H}_{01}$ diterima \\
\hline
\end{tabular}

Berdasarkan tabel 5 terlihat bahwa nilai sig (2-tailed) yang dihasilkan dari uji Paired Sample T-Test menunjukkan bahwa $\mathbf{H}_{01}$ gagal untuk ditolak yang berarti tidak terdapat perbedaaan NPM antara sebelum dan sesudah pengungkapan program CSR dikarenakan memiliki nilai sig yang lebih besar dari nilai probabilitasnya, yaitu 0,05 . Hal ini tidak sesuai dengan teori yang menujukkan bahwa perusahaan merupakan entitas yang beroperasi tidak hanya untuk kepentingan sendiri, namun juga harus memberikan manfaat bagi stakeholdernya. Apabila perusahaan dapat memaksimalkan manfaat yang diterima stakeholder maka akan timbul kepuasan bagi stakeholder yang nantinya akan meningkatkan nilai perusahaan. Hasil penelitian ini konsisten dengan Istiqomah (2011) yang menyatakan bahwa NPM tidak mengalami perbedaan sebelum dan setelah melaksanakan program CSR pada industri telekomunikasi.

Hipotesa kedua yang menyatakan terdapat perbedaaan $R O A$ antara sebelum dan sesudah pengungkapan program CSR. Hal ini telah dibuktikan dengan hasil uji Paired Sample T-Test dimana nilai signifikansi yang didapat adalah sebagai berikut.

Tabel 6 Hasil Paired Sample T- Test terhadap ROA

\begin{tabular}{cccc}
\hline Periode & Sig (2-tailed) & $\begin{array}{c}\text { Nilai Prob. } \\
\text { Terhadap } \boldsymbol{\alpha}=\mathbf{0 , 0 5}\end{array}$ & Kesimpulan \\
\hline 1 tahun sebelum dan 1 tahun sesudah & 0,233 & 0,05 & $\mathrm{H}_{02}$ diterima \\
1 tahun sebelum dan 2 tahun sesudah & 0,520 & 0,05 & $\mathrm{H}_{02}$ diterima \\
1 tahun sebelum dan 3 tahun sesudah & 0,387 & 0,05 & $\mathrm{H}_{02}$ diterima \\
2 tahun sebelum dan 1 tahun sesudah & 0,210 & 0,05 & $\mathrm{H}_{02}$ diterima \\
2 tahun sebelum dan 2 tahun sesudah & 0,535 & 0,05 & $\mathrm{H}_{02}$ diterima \\
\hline
\end{tabular}


Berdasarkan tabel 6 terlihat bahwa nilai sig (2-tailed) yang dihasilkan dari uji Paired Sample $T$-Test menunjukkan bahwa $\mathbf{H}_{\mathbf{0 2}}$ gagal untuk ditolak yang berarti tidak terdapat perbedaaan $R O A$ antara sebelum dan sesudah pengungkapan program CSR dikarenakan memiliki nilai sig yang lebih besar dari nilai probabilitasnya, yaitu 0,05 . Hasil penelitian ini konsisten dengan penelitian Agustin (2011) yang menunjukkan bahwa tidak terdapat perbedaan antara rata-rata profitabilitas perusahaan yang dihitung dengan rasio Return On Asset (ROA) sebelum dan sesudah perusahaan menerapkan CSR. Namun bertentangan dengan penelitian Istiqomah (2011) yang menyatakan bahwa terdapat perbedaan ROA sebelum dan setelah melaksanakan program corporate social responsibility pada industri telekomunikasi. Perbedaan ini terjadi karena bedanya jenis industri yang digunakan pada sampel penelitian ini, dimana penulis menggunakan industri pertambangan dan farmasi, sedangkan Istiqomah menggunakan industri telekomunikasi. Ukuran perusahaan dan jenis industri dapat menjadi salah satu faktor yang menjadikan ROA perusahaan sebelum dan sesudah penerapan CSR tidak terlihat perbedaannya, karena jika ukuran dan jenis industrinya berbeda, maka penggunaan masing-masing perusahaan terhadap aktiva yang dimilikinya juga akan berbeda-beda.

Hipotesa ketiga yang menyatakan terdapat perbedaaan $R O E$ antara sebelum dan sesudah pengungkapan program CSR. Hal ini telah dibuktikan dengan hasil uji Paired Sample T-Test dimana nilai signifikansi yang didapat adalah sebagai berikut:

Tabel 7 Hasil Paired Sample T-Test terhadap ROE

\begin{tabular}{cccc} 
Periode & Sig (2-tailed) & $\begin{array}{c}\text { Nilai Prob. } \\
\text { Terhadap } \boldsymbol{\alpha}=\mathbf{0 , 0 5}\end{array}$ & Kesimpulan \\
\hline 1 tahun sebelum dan 1 tahun sesudah & 0,880 & 0,05 & $\mathrm{H}_{03}$ diterima \\
1 tahun sebelum dan 2 tahun sesudah & 0,509 & 0,05 & $\mathrm{H}_{03}$ diterima \\
1 tahun sebelum dan 3 tahun sesudah & 0,547 & 0,05 & $\mathrm{H}_{03}$ diterima \\
2 tahun sebelum dan 1 tahun sesudah & 0,659 & 0,05 & $\mathrm{H}_{03}$ diterima \\
2 tahun sebelum dan 2 tahun sesudah & 0,240 & 0,05 & $\mathrm{H}_{03}$ diterima \\
\hline
\end{tabular}

Berdasarkan tabel 7 terlihat bahwa nilai sig (2-tailed) yang dihasilkan dari uji Paired Sample $T$-Test menunjukkan bahwa $\mathbf{H}_{\mathbf{0 3}}$ gagal untuk ditolak yang berarti tidak terdapat perbedaaan $R O E$ antara sebelum dan sesudah pengungkapan program CSR dikarenakan memiliki nilai sig yang lebih besar dari nilai probabilitasnya, yaitu 0,05 . Berdasarkan hasil penelitian ini, perusahaan masih belum mendapatkan peningkatan nilai profitabilitas terhadap ROE sesudah mengungkapkan kegiatan CSR, hal ini mungkin dikarenakan kegiatan sosial dan aktivitas lingkungan sebagai wujud tanggung jawab perusahaan terhadap lingkungan dan sosial di sekitarnya belum cukup baik pelaksanaannya sehingga dampaknya terhadap perusahaan belum terlihat. Nilai profitabilitas yang dimiliki perusahaan menunjukkan kinerja dari perusahaan tersebut, dimana semakin baik kinerja suatu perusahaan maka akan semakin menarik minat investor karena keuntungan atau return yang diharapkan juga akan semakin besar. Selain itu juga CSR merupakan manajemen dampak, dan karena dampak setiap sektor industri adalah berbeda-beda, maka dampak terhadap tingkat profitabilitas yang diperoleh oleh setiap industri juga berbeda-beda. Daniel Esty dan Andrew Winston dalam Green to Gold (2006) serta Christine Arena dalam The High Purpose Company (2007) melihat bahwa perusahaan-perusahaan yang dianggap memiliki kinerja CSR yang tinggi bukanlah perusahaan yang mencurahkan sumberdaya finansial terbanyak, melainkan perusahaan yang melekatkan CSR dengan strategi berbisnis, termasuk strategi bersaing. Oleh karena itu, perusahaan harus lebih berusaha lagi untuk menunjukkan kinerja terbaiknya agar keputusan yang diambil investor dapat menguntungkan perusahaan. 


\section{SIMPULAN}

Hasil penelitian ini menunjukkan hasil pengujian secara parsial dalam menguji kinerja perusahaan. Adapun kesimpulan dari pengujian yang membandingkan data rasio keuangan perusahaan untuk tahun sebelum dan sesudah pengungkapan Corporate Social Responsibility (CSR) adalah bahwa peningkatan nilai rata-rata yang terjadi pada rasio $N P M, R O A$, dan $R O E$ tersebut, berdasarkan hasil uji Paired Samples T-Test menunjukkan tidak terjadinya perbedaan nilai terhadap ketiga rasio tersebut untuk satu tahun sebelum dengan satu tahun sesudah pengungkapan CSR. Tingkat kinerja perusahaan mengalami peningkatan yang sangat minimum seperti pada nilai rata-rata $N P M$ dan $R O A$, sedangkan nilai $R O E$ mengalami penurunan yang lebih besar dibanding dengan peningkatan nilai yang dialami oleh NPM dan ROA. Namun, berdasarkan pengujian dengan Paired Samples T-Test menunjukkan tidak terjadinya perbedaan nilai terhadap ketiga rasio tersebut untuk untuk satu tahun sebelum dengan dua tahun sesudah pengungkapan CSR. Tingkat kinerja perusahaan mengalami peningkatan yang minimum seperti pada nilai rata-rata $N P M$ dan $R O A$, sedangkan nilai $R O E$ mengalami penurunan yang lebih besar dibanding dengan peningkatan nilai yang dialami oleh $N P M$ dan ROA. Namun, berdasarkan pengujian dengan Paired Samples T-Test menunjukkan tidak terjadinya perbedaan nilai terhadap ketiga rasio tersebut untuk untuk satu tahun sebelum dengan tiga tahun sesudah pengungkapan CSR.

Tingkat kinerja perusahaan mengalami peningkatan yang minimum seperti pada nilai rata-rata $N P M$ dan $R O A$, sedangkan nilai $R O E$ mengalami penurunan. Namun, berdasarkan pengujian dengan Paired Samples T-Test menunjukkan tidak terjadinya perbedaan nilai terhadap ketiga rasio tersebut untuk dua tahun sebelum dengan satu tahun sesudah pengungkapan CSR. Tingkat kinerja perusahaan mengalami peningkatan yang minimum seperti pada nilai rata-rata $N P M$ dan $R O A$, sedangkan nilai $R O E$ mengalami penurunan. Hasil pengujian terhadap rasio $N P M, R O A$, dan $R O E$ menunjukkan tidak terjadinya perbedaan untuk dua tahun sebelum dengan dua tahun sesudah pengungkapan CSR.

\section{Saran}

Hasil dari analisis perbedaan tingkat profitabilitas terhadap kinerja perusahaan belum terlihat untuk satu hingga tiga tahun kedepan, sehingga saran bagi peneliti adalah sebaiknya memperpanjang waktu pengamatan dari 3 tahun hingga 4 sampai 5 tahun kedepan serta menambah fokus penelitian pada CSR tidak hanya pada tingkat profitabilias saja, melainkan karakteristik perusahaan juga diikutsertakan, karena kedua hal ini saling berhubungan dalam hal pengungkapan CSR, seperti kepemilikan institusional, komposisi dewan komisaris independen dan ukuran perusahaan. Penelitian selanjutnya diharapkan tidak hanya meneliti pada perusahaan dalam industri pertambangan dan farmasi saja, tetapi juga menyertakan sampel dari perusahaan pulp and paper dan kimia yang telah melaksanakan program CSR. Keterbatasan Penelitian Tidak semua perusahaan pertambangan dan farmasi telah melakukan pengungkapan CSR serta menyajikan informasi kapan tahun mulai dilaksanakanya CSR. Selain itu juga, perusahaan pertambangan dan farmasi kebanyakan hanya menyajikan laporan keuangan untuk 5 tahun terakhir, sedangkan yang dipakai oleh peneliti adalah laporan keuangan untuk 6 tahun terakhir. Dalam penelitian ini kinerja perusahaan yang dianalisis hanya berdasarkan rasio keuangan saja, sedangkan ada aspek-aspek lain yang juga dapat mempengaruhi dalam hal pengungkapan CSR yang dapat dilakukan oleh perusahaan, seperti kepemilikan institusional, komposisi dewan komisaris dan ukuran perusahaan. Oleh karena itu penelitian ini tidak dapat menggambarkan keseluruhan aspek kinerja perusahaan. 


\section{DAFTAR PUSTAKA}

Agustin, C. P. (2011). Efek Penerapan Corporate Social Responsibility (CSR) Terhadap Tingkat Pofitabilitas, Pajak Penghasilan dan Biaya Operasi pada Perusahaan yang Terdaftar di Bursa Efek Indonesia, Jakarta: Universitas Pembangunan Nasional.

Ancok, D. (2005). Investasi Sosial. Jakarta: Pusat Penyuluhan Sosial.

Argumentasi Menentang Regulasi Dana CSR (II). Diakses tanggal Juni 24, 2012, dari www.csrindonesia.com.

Bursa Efek Indonesia. (n.d.). Diakses Februari 2, 2012, dari http://www.idx.co.id/. Corporate Social Responsibility. (n.d.). Diakeses Februari 10, 2012 , dari http://rosita.staff.uns.ac.id/2010/07/23/corporate-social-responsibility/.

Dunia Investasi. (n.d.). Diakses Februari 2, 2012, dari http://www.duniainvestasi.com/bei/.

Fraser, L. M., Ormiston, A. (2010). Understanding Financial Statements. New Jersey: Prentice Hall.

Gitman, L. J. (2011). Principle of Managerial Finance. Pearson.

Harahap, S. S. (2008). Analisis Kritis Atas Laporan Keuangan. Jakarta: Raja Frafindo Persada.

Ikatan Akuntan Indonesia. (2009). Standar Akuntansi Keuangan. Jakarta: Salemba Empat.

Istiqomah, L. (2011). Analisis Profitabilitas Perusahaan Sebelum dan Setelah Melaksanakan Program CSR (Corporate Social Responsibility) Pada Industri Telekomunikasi. Malang: Universitas Islam Negeri Malang.

Kasmir. (2009). Analisis Laporan Keuangan. Jakarta: Rajawali Pers.

Kuntari, Y., dan Sulistyani, A. (2007). Pengaruh Karakteristik Perusahaan Terhadap Pengungkapan Tanggung Jawab Sosial dalam Laporan Tahunan Perusahaan Indeks Letter Quality (LQ 45) Tahun 2005. ASET. Volume 9 Nomor 2. Agustus : 494-515.

Nurlela dan Islahudin. (2008). Pengaruh Corporate Social Responsibility terhadap Nilai Perusahaan dengan Prosentase Kepemilikan Manajemen sebagai Variabel Moderating. Simposium Nasional Akuntansi XI

Perbedaan Gross Margin, Operating Margin dan Net Margin (n.d.). Diakses Juni 23, 2012, dari http://tiaphari.com/2008/08/19/perbedaan-gross-margin-operating-margin-dan-net-margin/.

Priyatno, Duwi, (2010). Paham analisa statistik dengan SPSS. Jakarta: MediaKom.

Saidi, Z., dan Abidin, H. (2004). Menjadi Bangsa Pemurah: Wacana dan Praktek Kedermawanan Sosial di Indonesia. Jakarta: Piramedia.

Sayekti, Y., dan Wondabio, L. S. (2007). Pengaruh CSR Disclosure terhadap Earning Response Coefficient (Suatu Studi Empiris pada Perusahaan yang Terdaftar di Bursa Efek Jakarta), Paper dipresentasikan pada Simposium Nasional Akuntansi IX,Unhas, Makassar.

Sugiyono. (2008). Metode Penelitian Kuantitatif, Kualitatif dan R\&D. Bandung: Alfabeta. 